\section{The Centenary of Sir Joseph Banks, Bart.}

THE commemoration of the centenary of Sir Joseph Banks, Bart., who died on June 19, I 820 , was celebrated by the Linnean Society on Thursday last, as mentioned on p. 496 of NATURE for June I7. After the usual formal business, Dr. B. Daydon Jackson read the first communication on "Banks as a Traveller," speaking of his four overseas voyages - first, the visit to Newfoundland in H.M.S. Niger, on board which his friend Constantine Phipps, afterwards Lord Mulgrave, was a lieutenant; next, the adventurous voyage of the Enderavour, Lieut. Cook commander, when Banks so amply proved his value in many untoward events; third, the voyage to Iceland; and fourth, his trip to Rotterdam in 1773 , when he was still eager for an expedition to the North. The second paper, by Dr. A. B. Rendle, was entitled "Banks as a Patron of Science." Banks's life from his return to England in $177 \mathrm{I}$ until its close in 1820 was that of an enthusiastic, liberal, and generally far-sighted patron of science. A friendship began with King George, which steadily increased, and Banks was consulted on important matters of very various kinds. He became botanical adviser to the King in relation to the Royal Gardens at Kew, which developed under Banks's guidance, becoming the repository of plants of economic and ornamental value from all parts of the world. Banks initiated or encouraged voyages of exploration, and kept up an extensive correspondence with men interested in science overseas. His house in Soho Square was the rendezvous of students and men of all classes interested in schemes of philanthropy or science; his magnificent library and herbarium were at the service of other workers, and after his death were bequeathed to the British Museum. For fortytwo years he was president of the Royal Society. He was very closely, though indirectly, associated with the origin of the Linnean Society. Mr. James Britten, in the third paper, began by remarking that much of his paper was based upon the daily use of Banksian specimens for nearly half a century in the British Museum. The author showed that the popular belief that Banks left all his botanic work to his secretaries and curators, Solander and Dryander, was a mistaken one, and that Banlss displayed great botanic acquirements.

The president remarked that official records of the British Museum testified to the active interest taken by Banks in all matters connected with its advancement. and that keepers and trustees alike referred to him for his advice and decision.

Certain objects closely connected with Banks were exhibited.

\section{South-Eastern Union of Scientific Societies.}

THE twentv-fifth annual congress of the Union was held at Eastbourne on June $2-6$, under the presidency of Sir Edward Brabrook, who in his presidential address dealt with progress in anthropology and economics during the past quarter of a century. In regard to the latter, he expressed the opinion that the war seemed to have dismissed all economic orthodoxy into thin air, with unrestricted paper currency, reckless extravagance, trading by Government, and manipulation of markets, all of which had been borne with patience during war-time, but were intolerable in time of peace. Science had done what it could to provide sound instruction by the issue of standard works.

The second day's business hegan with a paper by NO. 2643 , VOL. IO5]
Comdr. E. A. Martin on "The Glaciation of the South Downs," in which he endeavoured to show that the chalk hills received their final curving by ice-agency, and attributed much of the "clay-with-flints" deposits and the chalk rubble of the dry valleys to the agency of glaciers, having their rise on the Downs when they were at a greater height, with greater precipitation, and a low snow-line. He had mapped out the blocks of sandstones, ironstones, and sarsens, and concluded that short rivers could not have transported them to where they are now found. He compared the ironstones with similar deposits which have been found at Lenham, on the North Downs, to be of Pliocene age. He referred the rounded contours of the chalk hills to the grinding action of ice, resulting in their appearance now as huge roches-moutonnées. Striations were not, as a rule, found, because the rocks were such as would rather crumble and perish under the pressure necessary to produce them. One sarsen at Stanmer was found, however, distinctly to be striated. The author thought that there had been two clear periods of glaciation : one before the deposition of the temperate marine muds at Selsea, at the base of which were the famous Selsea erratics, referable to the glaciation at the close of the Acheulian period, and a later one which gave rise to the RubbleDrift, after the development of the Mousterian culture. In a brief discussion which followed, the glaciation theory was opposed by Mr. T. Sheppard, of Hull.

Mr. C. C. Fagg read a paper on "First Steps in a Local Regional Survey," in continuation of the efforts which he has made for some years to stimulate the regional survey movement. Prof. Boulger, in the absence through illness of Miss G. Lister, read a paper on "The Eastern Extension of the Lusitanian Flora," with special reference to the locality.

Prof. E. B. Poulton delivered a public lecture on "Mimicry and Migrations of Insects," and this was attended by invitation by numerous boys' and girls' schools in the town. A paper was read by $\mathrm{Mr}$. R. Adkin on "Migrations of Butterflies and Moths in regard to the British Islands." Mr. Adkin dealt with flights of migrating Lepidoptera and movements of larvæ by the agency of the wind, and discussed the question of whether such occurrences are to be considered as chance happenings or as the result of voluntary action on the part of the migrants. Some account was given of observed immigrations on the coast near Eastbourne, and further evidence was asked for. Mr. Adkin showed how the geographical position of the British Islands rendered them singularly suitable for the observation of such phenomena, and suggested the lines of movement by which such immigrants would be likelv to reach our coasts. The naper was illustrated bv mans and diagrams and by exhibits of the insects referred to.

The matter of the enclosing of so much of the Downs during the last year or two by barbed-wire fences was discussed, and a resolution was carried with much enthusiasm asking that joint steps should be taken by several influential bodies to carry throuoh a scheme for the protection of rights of wav over the Downs, and for the acquisition for public use of typical stretches of them.

A large collection of wild flowers was on exhibition during the congress. Phyteuma spicatum was said to be growing in large quantities in East Sussex this vear, and orchids were found in profusion in and about Beachv Head. Excursions to Pevensey, Alfriston. East Dean, Old Eastbourne, and other places added interest to a verv successful.congress.

After one of the excursions the party returned to "Hodeslea" to tea. Huxley spent the later years of 
his life in Eastbourne, and occupied "Hodeslea," which is now the residence of the Union's treasurer. The house was built by Huxley in 1890 and he lived there until 1895 whilst his widow remained there until her death in IgI4. Mr. Adkin has recently placed a bronze tablet on the house relating these facts.

\section{Genetic Segregation, ${ }^{1}$}

\section{By W. Bateson, F.R.S.}

I ATER developments of genetics have been, in the 1 main, attempts to discover the nature and scope of segregation. Mendel proved that certain characters are determined by unit-factors. Their integrity is maintained by segregation, the capacity, namely, to separate unimpaired after combination with their opposites. We have been trying, first, to ascertain specifically what characters behave in this way, whether there is any limit to the scope of segregation or any classes of characters otherwise transmitted. Among characters known to be subject to segregation are illustrations of most of the features by which plants and animals are distinguished. In regard to two classes of characters the evidence for segregation is, nevertheless, rather noticeably imperfect. No quite clear proof exists that differences in number-meristic characters in the strict sense-are governed by factors comparable with those that control, for example, colour. The extra toe of the fowl and the single leaflet of the monophyllous strawberry are perhaps the best examples, but reservations may be entertained. Also, though segregation can be demonstrated in regard to quantitative characters, parental types thus distinguished often fail to re-appear, and the inheritance is subject to special complications.

Groups or complexes of factors are now recognised as sometimes segregatin $\sigma$ whole. Were it not that on occasion elements of the cons?lex become independent, the group would pass for one un-it-factor. The sexcomplex is an obvious example. Inte mediate flowercolours, like those of modern sweet peas, probably arise by this process. The plausible suggestion that the new terms are only rare cross-nvers in a closely linked series does not fit the evidence. A striking illustration appears in Cnothera, in which, as Renner lately showed, several groups of characters normally segregate as single factors. These complexes are in several forms not borne equally by the two sexes of the plant, and most of them cannot exist in the homozygous state. By these discoveries the Enothera problem is greatly elucidated.

The second question is to determine when in the life-cycles segregation can occur. Admittedly it is a phenomenon of cell-division. If we knew the animals only we might confidently adopt the view of Morgan that normal segregation happens during the maturation process at the stage of synapsis, when the maternal and paternal chromosomes are believed to conjugate in pairs. Most of the tarts of linkage may be thus well represented, but the absence of crossingover in the sex-heterozygote (Drosophila and silkworm) is not readily explicable, nor is there as yet extensive evidence that the number of linkage-systems agrees with that of the chromosomes-a primary postulate of Morgan's theory. The evidence for an orderly anastomosis, or even of any exchange of materials between chromosomes, is weak: and the visible features of chromosomes are scarcely suggestive of the prodigious heterogeneity requisite. Even if the linkage-systems correspond with the chromosomes,

I Abstract of the Croonian Lecture delivered before the Royal. Society on June 17.

No. 2643 , VOL. 105] which is a most attractive conjecture, exchange of material between chromosomes need not be essential to crossing-over. It may be doubted; however, whether the general course of cytological evidence does not point to the rôle of the chromosomes being rather passive than active.

That in plants segregation even in its normal course is not limited to the reduction-division is now certain. In Matthiola, Campanula, Begonia, and Cnothera the genetic composition of the male and female organs may be normally different, and segregation cannot have happened later than the constitution of these organs. This kind of segregation must result in Campanula carpatica (experiments of C. Pellew) and in Begonia Davisii from the peculiar genetic properties of the female complex, for it reappears in offspring derived from the female side for several generations at least, but not among those derived from the male side. Collins's evidence from Funaria proves further that sex-segregation may happen during the growth of a haploid form.

Periclinal chimæras and the production of distinct types from adventitious buds prove that segregation may take place during somatic development, whether in the differentiation of the layers or of the root. In the genetic properties of the tare-like rogues of peas there are features which not only illustrate the occurrence of gradational change in genetic properties, following somatic differentiation, but also show that this gradation affects the male and female organs differently. From these facts it must be concluded that normal and orderly segregation (apart from chance sporting) can occur at various celldivisions, and not exclusively at reduction. Not impossibly these somatic segregations may be accompanied by some visible cvtological differentiation, but that question must not be prejudged.

Having regard to the fundamental distinctions between the morphological relations of the germ-cells to the soma in animals and in the flowering plants, it is not surprising that the processes of segregation should be differently effected in these two groups of organisms.

\section{Colour Index of the British Isles.}

$A \mathrm{~T}$ a meeting of the Royal Anthropological InstiA tute held on June 15, Prof. Arthur Keith, expresident, in the chair, Prof. F. G. Parsons read a paper on "The Colour Index of the British Isles." He first reviewed the different ways of constructing an index of nigrescence, and directed attention to what he considered their weak points. Prof. Parsons proposed as a simple and workable index that the percentage in any group of individuals with dark brown and black hair should be added to the percentage with eyes in which any brown pigment is present, and the result divided by two. For practical purposes he found it better to record the percentages of dark hair and dark eyes separately. He then proceeded to examine the large mass of statistics collected by Dr. Beddoe in the middle of the last century, and pointed out that the first deduction was that women are in the mass darker than men, and that where the people are fairest the difference between the sexes is greatest, as the following table shows:

\begin{tabular}{|c|c|c|c|c|c|}
\hline \multirow{3}{*}{\multicolumn{2}{|c|}{4 Northern Counties }} & \multirow{2}{*}{\multicolumn{2}{|c|}{ No. of records }} & \multirow{3}{*}{$\begin{array}{l}\text { Men } \\
26 \cdot 2\end{array}$} & \multirow{3}{*}{$\begin{array}{c}\text { Women } \\
3.3 .5\end{array}$} \\
\hline & & & & & \\
\hline & & $\cdots$ & 1767 & & \\
\hline 3 Eastern & $"$ & $\ldots$ & $I_{5}{ }^{6} 3$ & $34 \cdot 4$ & $38 \cdot 2$ \\
\hline Western & ," & $\ldots$ & 4057 & $45 \cdot 5$ & $46 \cdot 7$ \\
\hline
\end{tabular}

